\title{
Endocrine regulation of metabolism in sheep given kale (Brassica oleracea) and ryegrass (Lolium perenne) - clover (Trifolium repens) fresh-forage diets
}

\author{
BY T. N. BARRY* AND T. R. MANLEY \\ Invermay Agricultural Research Centre, Private Bag, Mosgiel, New Zealand \\ AND CAROLYN REDEKOPP \\ Department of Endocrinology, Princess Margaret Hospital, Christchurch, New Zealand \\ AND T. F. ALLSOP \\ Wallaceville Research Centre, Upper Hutt, New Zealand
}

(Received 1 November 1984 - Accepted 15 February 1985)

\begin{abstract}
1. Diets of fresh kale (Brassica oleracea) and ryegrass (Lolium perenne) - clover (Trifolium repens) herbage were fed to growing sheep in three experiments. In Expts 1 and 3 the sheep were confined indoors and fed at hourly intervals, and all were given supplementary iodine to counteract kale goitrogens. Lambs grazed the two forages for 24 weeks in Expt 2, with and without intramuscular injections of iodized oil. The kale and herbage contained respectively 11 and $<0.1 \mathrm{~g} \mathrm{~S}$-methyl-L-cysteine sulphoxide (SMCO)/kg dry matter (DM) and values for readily fermentable: structural carbohydrate (CHO) were $3 \cdot 1$ and $0 \cdot 8$, respectively.
\end{abstract}

2. Blood samples were withdrawn from indwelling catheters (Expts 1 and 3) or venipuncture (Expt 2) and the plasma analysed for a range of hormones using radioimmunoassay procedures. Glucose irreversible loss (GIL) was measured in Expt 1 using primed continuous infusions of D-[U-14 Clglucose. Samples of adipose tissue were removed from the shoulder area in Expt 3, and rates of $\mathrm{D}-\left[\mathrm{U}-{ }^{14} \mathrm{C}\right] \mathrm{glucose}$ and $\left[\mathrm{U}-{ }^{14} \mathrm{C}\right]$ acetate incoporation and oxidation were measured in vitro, together with the rate of glycerol release.

3. In the presence of supplementary $\mathbf{I}_{2}$, kale feeding was associated with an elevation in plasma concentration of free thyroxine $\left(T_{4}\right)$. Regardless of $I_{2}$ supplementation, sheep fed on kale had much higher plasma growth hormone concentrations than sheep fed on ryegrass-clover herbage, and this was accompanied by reduced plasma somatostatin concentrations.

4. Plasma insulin and glucagon concentrations were similar for sheep fed on the two diets; GIL tended to be slightly but not significantly greater $(9.4 \%)$ for sheep fed on kale than for those fed on ryegrass-clover herbage.

5. Kale feeding was associated with increased uptakes of acetate and glucose into adipose tissue, reduced rates of oxidation of both substrates and no difference in rate of glycerol release. Each $1 \mathrm{nmol}$ increase in glucose uptake was associated with $8.7 \mathrm{nmol}$ acetate uptake $(P<0.001)$.

6. It is proposed that ruminants counteract protein inactivation, caused by production of dimethyl disulphide from SMCO in the rumen, through increasing circulating concentrations of growth hormone and $\mathrm{T}_{4}$, which then stimulate synthesis of replacement body proteins.

The feeding value of herbage has been defined as the animal production response to grazing a defined forage, and is a function of both voluntary dry matter (DM) intake and nutritive value: DM eaten (Ulyatt, 1973). Kale (Brassica oleracea) diets are unique in containing much higher values of readily-fermentable : structural carbohydrate (CHO) than normal ryegrass (Lolium perenne)-clover (Trifolium repens) herbage ( $3 \cdot 0$ v. $0 \cdot 8)$, and also containing the free amino acid S-methyl-L-cysteine sulphoxide (SMCO) which is absent from other forage species (Barry et al. 1984a). SMCO in brassica diets is fermented by rumen bacteria to dimethyl disulphide, which inactivates proteins through blocking sulphydryl groups (Fig. 1), and is the cause of haemolytic anaemia associated with feeding brassica diets to

* Present address: Department of Animal Science, Massey University, Palmerston North, New Zealand. 


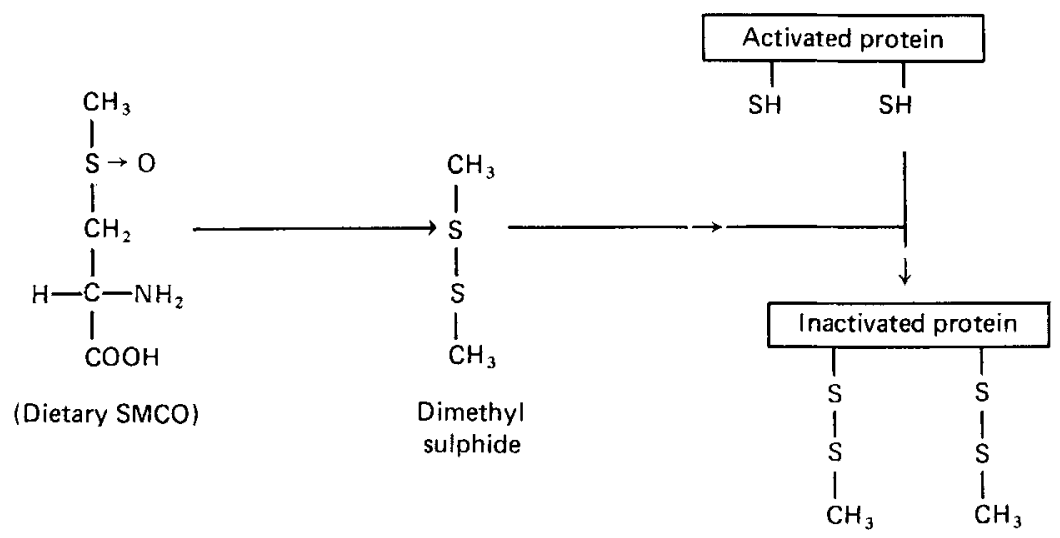

Fig. 1. Proposed mechanism of protein inactivation by dimethyl disulphide, produced from rumen fermentation of S-methyl-L-cysteine sulphoxide (SMCO) in ruminants fed on brassica diets

ruminants (Smith, 1974). SMCO depresses the feeding value of kale diets to growing lambs, measured by live-weight gain and wool growth (Barry et al. 1984 b), due mainly to depressing voluntary intake (Barry et al. 1982a).

Growing lambs can adapt to nutritional problems caused by SMCO after grazing on kale for 6 weeks or more (Barry et al. 1981 a, 1984b). The primary objective of the present investigation was to measure endocrine changes associated with kale feeding, with a view to establishing their role in the adaptation process and effects on nutrient metabolism. Ryegrass-clover herbage grown on the same soil type at the same time was used as a control diet. A secondary objective was to compare glucose production in growing sheep fed on kale and ryegrass-clover forages differing markedly in the ratio, readily-fermentable: structural $\mathrm{CHO}$. The results showed marked elevations in plasma growth hormone and thyroxine concentrations associated with kale feeding, and it is proposed that this acts as a mechanism for stimulating synthesis of replacement proteins.

\section{EXPERIMENTAL}

\section{Forages and experimental design}

Three experiments were conducted using diets of marrow-stem kale (cv. Maris Kestrel) and ryegrass-white clover pasture. The kale crops were shown in the spring and fed to animals during the autumn-winter period, after a growing period of 6-8 months. The pasture used contained $(w / w)$ approximately 0.90 ryegrass and $0 \cdot 10$ clover, and was grown during the autumn-winter period. All forages were fed in the fresh state.

\section{Animals}

Castrated male Romney sheep were used in all three experiments. Those used in Expts 1 and 3 were aged approximately 20 months, whilst lambs aged 5 months were used in Expt 2. At the commencement of Expts 1 and 3 all sheep were given an oral drench supplying anthelmintic plus $2 \mathrm{mg}$ selenium as sodium selenate, and a $1 \mathrm{ml}$ intramuscular injection of iodized oil supplying $475 \mathrm{mg}$ iodine (Lipiodol; May \& Baker, New Zealand) to counteract the goitrogenic properties of inorganic thiocyanate ion released on hydrolysis of glucosinolates present in kale. 


\section{Expt 1}

The sheep were housed indoors in metabolism cages, and fed on chopped forms of the two diets at hourly intervals from overhead belt-feeders. Continuous artificial lighting was supplied. Nine sheep were fed on kale and nine were fed on ryegrass-clover herbage for 6 weeks. Each diet was offered to give a range of DM intakes from 0.40 to $0.85 \mathrm{~kg} \mathrm{DM} / \mathrm{d}$. During week 4 , indwelling catheters were placed in both jugular veins, and glucose irreversible loss (GIL) measured using a primed $6 \mathrm{~h}$ continuous infusion of $\mathrm{D}-\left[\mathrm{U}-{ }^{14} \mathrm{C}\right]$ glucose as described by Barry et al. (1982b). Blood samples for endocrine assays were taken by jugular catheter from all sheep at 13.00 hours on $4 \mathrm{~d}$ during week 5 . Separate plasma samples, generally $1 \mathrm{ml}$, were prepared for each hormone determination by pooling $0.25 \mathrm{ml}$ portions from each of the four sampling times and storing at $-20^{\circ}$. The proteinase inhibitor Trasylol (Bayer, Leverkusen, W. Germany) was added to the tubes (1000 kIU/ml plasma) for glucagon and somatostatin assay and the tubes lyophilized before the plasma was added. Harnesses for faecal collection were fitted during week 6 and digestibility of energy determined. Metabolizable energy (ME) intake was calculated as $0.82 \times$ digestible energy (DE) intake.

\section{Expt 2}

Forty-eight lambs of initial weight $23.6 \mathrm{~kg}$ grazed each forage for 24 weeks, with half of each group being given $1 \mathrm{ml}$ intramuscular injections of iodized oil supplying $475 \mathrm{mg} I_{2}$ during weeks 1 and 12. Full details of the experiment have been described by Barry et al. (1983). Blood samples were taken by venipuncture from sixteen animals per treatment group (sixty-four animals overall) at the end of weeks 6, 18 and 24, and the plasma stored at $-20^{\circ}$ pending hormone assay.

\section{Expt 3}

Six animals of initial live weight $54.7 \mathrm{~kg}$ were kept indoors in pens and given $0.65 \mathrm{~kg} \mathrm{DM} / \mathrm{d}$ at hourly intervals from overhead belt-feeders for 6 weeks. Continuous artificial lighting was provided. Ryegrass-clover herbage was given for weeks 1-3 and kale for weeks 4-6. An indwelling catheter was placed in the left jugular vein during week 2, and blood samples withdrawn for endocrine assays during weeks 3 and 6 as described in Expt 1. On the last day of ryegrass-clover and kale feeding, a sample of adipose tissue was removed under local anaesthetic (Xylocaine; Astra Chemicals, Sydney) from the shoulder area of all animals, and maintained at $37^{\circ}$ in physiological saline $(9 \mathrm{~g}$ sodium chloride $/ \mathrm{l})$.

\section{Laboratory methods}

Insulin-like growth factor 1 (IGF1) was determined as described by Gluckman \& Butler (1983). All other hormone concentrations in plasma were determined by standard radioimmunoassay procedures as described by Barry et al. $(1982 b)$. Free $\mathrm{T}_{4}$ and free triiodothyronine $\left(T_{3}\right)$ indices were computed as described by Barry et al. $(1981 b)$ from the thyroxine-binding:globulin-binding ratio (TBGbr; a measure of the degree of saturation of the plasma proteins which transport thyroid hormones) and the total plasma concentration of each hormone. Free $T_{4}$ and free $T_{3}$ are indirect indices of the free concentration of each hormone, other studies from this laboratory having established correlations between free concentrations determined by radioimmunoassay and calculated free indices of 0.92 for $T_{4}$ and 0.89 for $T_{3}$ (T. N. Barry and W. A. Sadler, unpublished results).

Rates of lipogenesis in adipose tissue were determined from measuring rates of $\left[\mathrm{U}-{ }^{14} \mathrm{C}\right]$ acetate and $\mathrm{D}-\left[\mathrm{U}-{ }^{14} \mathrm{C}\right]$ glucose uptake, using $50 \mathrm{-mg}$ slices incubated for $2 \mathrm{~h}$ at $37^{\circ}$ in the in vitro procedures of Pike \& Roberts $(1980,1981)$. Ovine insulin $(25 \mu \mathrm{g})$ and adrenaline 
bitartrate $(50 \mu \mathrm{g})$ were added to the $2.5 \mathrm{ml}$ buffer in each flask. Rates of oxidation of $\left[\mathrm{U}-{ }^{14} \mathrm{C}\right]$ acetate and $\mathrm{D}\left[\mathrm{U}-{ }^{14} \mathrm{C}\right] \mathrm{glucose}$ were determined by trapping and counting ${ }^{14} \mathrm{CO}_{2}$ as described by Pike \& Roberts $(1980,1981)$. Glycerol release, a measure of lipolysis, was measured in the flasks used for both the acetate and glucose incubation using the enzymic method of Wieland (1974).

In the determination of GIL, the deproteinized plasma fraction containing neutral compounds was collected, and specific activity determined using the procedure of Schmidt et al. (1975). Initial tests showed that glucose standards added to the ion-exchange columns were quantitatively recovered in the eluates, and that more than $95 \%$ of the infusate radioactivity was recovered in the previously described fraction. Glucose concentration was determined by the glucose oxidase (EC 1.1.3.4) procedure (Trinder, 1969). In the calculation of GIL, infusate radioactivity was corrected for the small proportion not present as glucose.

Carbohydrate fractionation of the diets was carried out as described by Bailey (1967). SMCO was determined by the method of Gosden (1979).

\section{Statistical methods}

Analysis of variance procedures were used. In Expt 1, ME intake was used as the covariate, with the slopes quoted being based on pooled within-treatment variation only, the slopes not being significantly different for each diet $(P>0.05)$. Treatment differences in Expt 2 were assessed using residual between animal variability as the error term, full details of the design being given by Barry et al. (1983).

RESULTS

Chemical composition of diets

Relative to ryegrass-clover herbage, kale diets contained greater concentrations of readilyfermentable CHO (soluble $\mathrm{CHO}$ + pectin), lower concentrations of structural $\mathrm{CHO}$ (hemicellulose + cellulose), lower concentrations of total nitrogen and much higher concentrations of total S (Table 1; Barry et al. 1983). SMCO was present in the kale diets at $10-12 \mathrm{~g} / \mathrm{kg}$ DM and was virtually absent from ryegrass-clover herbage.

\section{Expt 1}

Mean ME intakes (MJ/d) were 6.6 (range 9.6-4.2) and 7.2 (range 9.6-5.0) for the sheep fed on kale and ryegrass clover herbage respectively. Increments in ME intake (Table 2) were associated with a depression in plasma growth hormone concentration, and with increases in the concentration of insulin, glucagon and GIL. Plasma free $T_{3}$ index was strongly related to $M E$ intake and free $T_{4}$ index weakly related to $M E$ intake.

When adjusted to equal ME intake (6.9 MJ/d), plasma TBGbr was greater for sheep fed on kale than for those fed on ryegrass-clover herbage $(P<0.05$; Table 3$)$. Kale feeding was associated with increased circulating concentrations of $T_{4}$, which attained significance for free $\mathrm{T}_{4}$ index $(P<0.01)$, but similar total and free $\mathrm{T}_{3}$ concentrations to those of sheep fed on ryegrass-clover herbage. Kale feeding was also associated with an increase in plasma growth hormone concentration $(P<0.05)$ and a non-significant decrease in somatostatin concentration (Table 3). Plasma concentrations of insulin, glucagon and prolactin were similar $(P>0.05)$ for sheep fed on the two diets. GIL was slightly but not significantly greater for sheep fed on kale than for those fed on ryegrass-clover. 
Table 1. Expts 1 and 3. Chemical composition $(\mathrm{g} / \mathrm{kg}$ dry matter $(D M)$ ) of fresh kale (Brassica oleracea) or ryegrass (Lolium perenne) - clover (Trifolium repens) forages fed to sheep

\begin{tabular}{|c|c|c|c|c|}
\hline & \multicolumn{2}{|c|}{ Expt 1} & \multicolumn{2}{|c|}{ Expt 3} \\
\hline & Kale & $\begin{array}{l}\text { Ryegrass- } \\
\text { clover }\end{array}$ & Kale & $\begin{array}{l}\text { Ryegrass- } \\
\text { clover }\end{array}$ \\
\hline Soluble $\mathrm{CHO}$ & 284 & 172 & 241 & 127 \\
\hline Pectin & 110 & 34 & 108 & 29 \\
\hline Hemicellulose & 51 & 119 & 46 & 125 \\
\hline Cellulose & 68 & 126 & 73 & 112 \\
\hline Lignin & 43 & 68 & 59 & 108 \\
\hline Readily-fermentable $\mathrm{CHO}$ : structural $\mathrm{CHO}$ & $3 \cdot 31$ & 0.84 & $2 \cdot 93$ & 0.71 \\
\hline Total nitrogen & $34 \cdot 4$ & $40 \cdot 2$ & $33 \cdot 4$ & 45.3 \\
\hline Total sulphur & ND & ND & $8 \cdot 5$ & $3 \cdot 6$ \\
\hline SMCO & $10 \cdot 6$ & $<0.1$ & 11.8 & $<0 \cdot 1$ \\
\hline
\end{tabular}

CHO, carbohydrate; SMCO, S-methyl-L-cysteine sulphoxide; ND, not determined.

Table 2. Expt 1. Rates of change in plasma hormone concentrations and glucose irreversible loss $(G I L)$ per $M J$ metabolizable energy intake in sheep

(Values for combined regression calculation with nine animals given each diet)

\begin{tabular}{lccc}
\hline \hline & Slope & SE & $\begin{array}{c}\text { Statistical } \\
\text { significance }\end{array}$ \\
\hline TBGbr (relative units) & 0.042 & 0.0169 & $*$ \\
Free $\mathrm{T}_{4}$ index (relative units) & 2.1 & 1.19 & $\dagger$ \\
Free $\mathrm{T}_{3}$ index (relative units) & 0.13 & 0.040 & $*$ \\
Growth hormone $(\mu \mathrm{g} / \mathrm{l})$ & -1.34 & 0.532 & $*$ \\
Insulin (mU/1) & 0.74 & 0.338 & $*$ \\
Glucagon (ng/l) & 6.7 & 3.16 & $* * *$ \\
GIL (mg/min) & 6.3 & 1.29 & $*$ \\
\hline \hline
\end{tabular}

TBGbr, thyroxine-binding : globulin-binding ratio; $T_{4}$, thyroxine; $T_{3}$, triiodothyronine. $\dagger P<0 \cdot 10,{ }^{*} P<0.05,{ }^{* *} P<0.01, * * * P<0.001$.

\section{Expt 2}

Lambs grazing kale had higher plasma growth hormone concentrations than lambs grazing ryegrass-clover herbage $(P<0.05$; Table 4$)$, with the response being independent of $\mathrm{I}_{2}$ administration and of similar magnitude after 6 and 24 weeks of grazing. Free $T_{4}$ index, measured at week 18 , was understandably depleted in the group grazing kale and not given supplementary $I_{2}$. However, free $T_{4}$ index of $I_{2}$-supplemented animals grazing kale was markedly greater than for either of the groups (with or without $\mathrm{I}_{2}$ ) grazing ryegrass-clover herbage $(P<0.001)$. This response in $\mathrm{T}_{4}$ progressively increased with time to attain stable values by week 18 , whilst $T_{3}$ concentration in this group was similar to that of ryegrassclover-fed animals (Barry et al. 1983).

Although both wool growth and live-weight gain tended to be increased by $I_{2}$ supplementation in sheep grazing kale $(P<0.01)$, wool growth rate in $\mathrm{I}_{2}$-supplemented lambs was still less than that recorded for lambs grazing ryegrass-clover herbage $(P<0.001)$, despite rates of live-weight gain being similar for the two groups (Table 4). 
Table 3. Expt 1. Plasma concentrations of thyroid, pituitary and pancreatic hormones, and glucose irreversible loss (GIL) of sheep, after adjustment of diets to equal metabolizable energy intake

(Mean values with their standard errors of differences for nine animals per diet)

\begin{tabular}{|c|c|c|c|c|}
\hline Diet . & $\begin{array}{c}\text { Kale } \\
\text { (Brassica oleracea) }\end{array}$ & $\begin{array}{l}\text { Ryegrass (Lolium perenne)- } \\
\text { clover (Trifolium repens) }\end{array}$ & SED & $\%$ \\
\hline Total $\mathrm{T}_{4}(\mathrm{nmol} / \mathrm{l})$ & $60 \cdot 6$ & $52 \cdot 9$ & 4.04 & \\
\hline Total $\mathrm{T}_{3}(\mathrm{nmol} / \mathrm{l})$ & $1 \cdot 30$ & $1 \cdot 33$ & 0.091 & \\
\hline TBGBbr (relative units) & $1 \cdot 22$ & $1 \cdot 07$ & 0.067 & \\
\hline Free $T_{4}$ index (relative units) & $73 \cdot 6$ & $56 \cdot 1$ & $4 \cdot 72$ & \\
\hline Free $T_{3}$ index (relative units) & $1 \cdot 61$ & $1 \cdot 44$ & $0 \cdot 158$ & \\
\hline Somatostatin (ng/1) & $19 \cdot 2$ & $27 \cdot 1$ & $5 \cdot 44$ & \\
\hline Growth hormone $(\mu \mathrm{g} / 1)$ & $7 \cdot 8$ & $3 \cdot 0$ & $2 \cdot 09$ & \\
\hline Prolactin $(\mu \mathrm{g} / 1)$ & $43 \cdot 4$ & $35 \cdot 4$ & $14 \cdot 20$ & \\
\hline Insulin (m U/1) & $15 \cdot 2$ & $15 \cdot 9$ & $1 \cdot 38$ & \\
\hline Glucagon (ng/l) & $155 \cdot 2$ & $165 \cdot 1$ & $12 \cdot 80$ & \\
\hline GIL (mg/min) & $58 \cdot 3$ & $53 \cdot 3$ & $3 \cdot 74$ & \\
\hline
\end{tabular}

$T_{4}$, thyroxine; $T_{3}$, triiodothyronine; TBGbr, thryoxine-binding : globulin-binding ratio.

Table 4. Expt 2. Plasma growth hormone concentrations and free thyroxine $\left(T_{4}\right)$ index, wool growth and live-weight gain in growing sheep grazing diets of kale (Brassica oleracea) or ryegrass (Lolium perenne) - clover (Trifolium repens) herbage for 24 weeks

(Mean values with their standard errors of differences for sixteen and twenty-four animals per treatment group for hormone and growth determinations respectively)

\begin{tabular}{|c|c|c|c|c|c|c|}
\hline \multirow[t]{2}{*}{ Diet. } & \multirow{2}{*}{$\begin{array}{l}\text { Period of grazing } \\
\text { (weeks) }\end{array}$} & \multicolumn{2}{|c|}{ Kale } & \multicolumn{2}{|c|}{ Ryegrass-clover } & \multirow[b]{2}{*}{ SED } \\
\hline & & No $I_{2}$ & $+\mathrm{I}_{2}$ & No $I_{2}$ & $+\mathrm{I}_{2}$ & \\
\hline \multirow[t]{2}{*}{ Growth hormone $(\mu \mathrm{g} / 1)$} & 6 & $3 \cdot 1$ & $3 \cdot 2$ & 1.6 & $1 \cdot 7$ & 0.86 \\
\hline & 24 & 3.7 & $3 \cdot 3$ & 1.8 & i. 1 & 1.01 \\
\hline Free $T_{4}$ index (relative units) $*$ & 18 & $3 \cdot 3$ & $105 \cdot 0$ & $36 \cdot 8$ & 43.9 & 3.85 \\
\hline $\begin{array}{l}\text { Wool growth }\left(\mathrm{mg} / 10^{4} \mathrm{~mm}^{2}\right. \\
\text { per d)* }\end{array}$ & $1-24$ & $95 \cdot 5$ & $102 \cdot 6$ & $118 \cdot 3$ & $118 \cdot 1$ & $4 \cdot 35$ \\
\hline Live-wt gain $(\mathrm{g} / \mathrm{d})^{*}$ & $1-24$ & 108 & 118 & 110 & 111 & 4.47 \\
\hline
\end{tabular}

* Calculated from Barry et al. (1983).

\section{Expt 3}

Sheep fed on kale had higher plasma concentrations of $\mathrm{T}_{4}(P<0.05)$ and growth hormone $(P<0.05)$ and lower concentrations of somatostatin $(P<0.05)$ than sheep fed on ryegrass-clover herbage (Table 5 ), with these responses being the same as those observed in Expt 1. Plasma IGF1 concentrations also tended to be greater in sheep fed on kale, but the effect did not attain significance $(P>0.05)$. Concentrations of insulin and $\mathrm{T}_{3}$ were not affected by diet.

Kale feeding was associated with increased uptakes of acetate $(P<0.05)$ and of glucose $(P<0.01)$ by adipose tissue (Table 5), reduced oxidation of glucose $(P<0.05)$ and a tendency for reduced oxidation of acetate that did not attain significance $(P>0.05)$. Rate of glycerol release was variable, with no treatment effect being evident. 
Table 5. Expt 3. Plasma hormone concentrations, and rates of $\left[U-{ }^{14} C\right]$ acetate and $\mathrm{D}-\left[U-{ }^{14} \mathrm{C}\right]$ glucose uptake and oxidation in vitro by adipose tissue slices, together with rates of glycerol release in sheep

(Mean values with their standard errors of differences for six animals per diet)

\begin{tabular}{|c|c|c|c|}
\hline Diet... & $\begin{array}{c}\text { Kale } \\
\text { (Brassica oleracea) }\end{array}$ & $\begin{array}{l}\text { Ryegrass (Lolium perenne)- } \\
\text { clover (Trifolium repens) }\end{array}$ & SED \\
\hline \multicolumn{4}{|c|}{ Plasma hormone concentration } \\
\hline Total $\mathrm{T}_{4}(\mathrm{nmol} / \mathrm{l})$ & $73 \cdot 5$ & $59 \cdot 3$ & 5.69 \\
\hline Total $\mathrm{T}_{3}(\mathrm{nmol} / \mathrm{l})$ & 1.06 & 1.21 & $0 \cdot 191$ \\
\hline TGBbr (relative units) & 1.04 & 1.04 & 0.068 \\
\hline Free $\mathrm{T}_{4}$ index (relative units) & $76 \cdot 2$ & $62 \cdot 0$ & 8.08 \\
\hline Free $T_{3}$ index (relative units) & 1.08 & 1.25 & 0.199 \\
\hline Somatostatin $(\mathrm{ng} / \mathrm{l})$ & $21 \cdot 9$ & $32 \cdot 8$ & $4 \cdot 45$ \\
\hline Growth hormone $(\mu \mathrm{g} / \mathrm{l})$ & $3 \cdot 2$ & 1.9 & 0.47 \\
\hline IGF1 $(\mu \mathrm{g} / \mathrm{l})$ & $97 \cdot 5$ & $64 \cdot 2$ & 22.6 \\
\hline Insulin (mU/l) & $21 \cdot 1$ & $18 \cdot 3$ & 3.49 \\
\hline \multicolumn{4}{|c|}{ Adipose tissue uptake, oxidation and glycerol release } \\
\hline \multicolumn{4}{|c|}{ Uptake* (nmol/g wet tissue per $\mathrm{h})$} \\
\hline Acetate & $1148 \cdot 7$ & $445 \cdot 4$ & $300 \cdot 11$ \\
\hline Glucose & $119 \cdot 4$ & $31 \cdot 6$ & $25 \cdot 71$ \\
\hline \multicolumn{4}{|l|}{ Oxidation* (nmol/g wet tissue per h) } \\
\hline Acetate & 111.8 & 136.9 & $19 \cdot 77$ \\
\hline Glucose & $30 \cdot 4$ & $43 \cdot 8$ & $5 \cdot 25$ \\
\hline Glycerol release (nmol/g wet tissue per $\mathrm{h}$ ) & $450 \cdot 0$ & $680 \cdot 8$ & 249.85 \\
\hline
\end{tabular}

$T_{4}$, thyroxine; $T_{3}$, triiodothyronine; TGBbr, thyroxine-binding: globulin-binding ratio; IGF1, insulin-like growth factor 1 .

* Amounts of $\left[\mathrm{U}-{ }^{14} \mathrm{C}\right]$ acetate and $\mathrm{D}-\left[\mathrm{U}-{ }^{14} \mathrm{C}\right]$ glucose either incorporated into adipose tissue or oxidized to carbon dioxide.

Individual regressions of acetate uptake (AcU; $\mathrm{nmol} / \mathrm{g}$ wet tissue per $\mathrm{h}$ ) $v$. glucose uptake (GlU; nmol/g wet tissue per h) did not differ for sheep fed the two diets $(P>0.05)$, and the combined regression was as follows:

$$
\mathrm{AcU}=139.8(\mathrm{SE} 140.89)+8.7(\mathrm{SE} 1.46) \mathrm{GIU} \quad(r 0.883, P<0.001)
$$

\section{DISCUSSION}

\section{Endocrine response to SMCO}

Feeding kale diets containing SMCO was specifically associated with increased plasma concentrations of growth hormone and free $T_{4}$, with none of the other hormones measured being affected. In growing ruminants, growth hormone stimulates both protein synthesis and deposition, with these effects being enhanced by $T_{4}$ (Trenkle, 1980). It therefore seems that the animal responds to protein inactivation caused by dimethyl disulphide by increasing the secretion of hormones that will promote increased rates of replacement protein synthesis. $T_{4}$ stimulates erythroetin-induced erythropoeis in human and mouse marrow-bone cells with a potency slightly greater than $T_{3}$ (Chopra \& Solomon, 1980); an additional role for $T_{4}$ may therefore be to stimulate replacement erythrocyte synthesis in kale-fed sheep with haemolytic anaemia.

Injection of growth hormone into growing animals stimulates $\mathbf{N}$ retention but reduces wool growth (Wheatley et al. 1966; Wallace, 1979). The hormone thus directs amino acid flow away from wool-protein synthesis and into body-protein deposition. Higher plasma 
growth hormone concentration may thus explain the lower wool growth rate of lambs grazing kale than those grazing ryegrass-clover pasture in Expt 2, especially in the presence of $I_{2}$ supplementation to counteract goitrogens and $I_{2}$ deficiency.

\section{Glucose and lipid metabolism}

Lipogenesis from both acetate and glucose was greater in sheep fed on kale than in those fed on ryegrass-clover and, as found by Bauman \& Davis (1975) for a range of ruminant diets, acetate was taken up by adipose tissue for lipid synthesis in much greater quantities than glucose. In a review, Trenkle (1981) concluded that growth-hormone administration increased plasma glucose concentration in growing animals, and in some circumstances it has increased GIL in lactating cattle (McDowell et al. 1983). The elevation in GIL caused by kale feeding, associated with raised plasma concentrations of growth hormone, was small $(+9.4 \%)$ and failed to attain statistical significance. Nevertheless, the small increase in GIL could at least be a contributing factor (eqn (1)) in the greater uptake of acetate by adipose tissue from kale-fed sheep.

\section{Possible dietary regulation of growth hormone and thyroxine secretion}

In addition to synthesis in hypothalamic tissue, thyrotrophin-releasing hormone (TRH; Morley et al. 1977) and somatostatin (Larsson et al. 1979) have been detected in pancreatic and intestinal tissue. Growth-hormone-releasing factor (GHRF) has also been isolated and purified from a pancreatic tumour (Rivier et al. 1982), implying that it may well be produced in much lower concentrations by normal pancreatic tissue. Despite their detection, no physiological role has been attributed to these three peptides found in gut tissue. One possibility in the present work is that damage to proteins in gut tissue by dimethyl disulphide could have promoted increased release of TRH and GHRF and decreased somatostatin release from the gut, which in turn could have promoted release of thyrotrophin and growth hormone from the pituitary. Of these three peptides, only somatostatin was measured in the present study, and kale feeding was associated with a tendency to lower its circulating concentration, which attained significance in Expt 3 but not in Expt 1. Involvement of TRH and GHRF released from the gut remains a speculative hypothesis; it is without proof in the present study, and is merely suggested as a possible mechanism where change in a dietary component might alter circulating concentrations of $\mathrm{T}_{4}$ and growth hormone.

In conclusion, high dietary concentrations of SMCO (7-16 g/ $\mathrm{kg} \mathrm{DM})$ in kale diets are definitely classified as detrimental, because of the anaemia produced and their depressing effects on voluntary intake (Barry et al. 1982a) and on body growth (Barry et al. 1984 ). The increased growth hormone and $T_{4}$ secretion observed here may be one mechanism whereby ruminants adapt to diets containing SMCO, and show improved rates of body growth after 6 weeks of feeding on the crop. It is proposed that growth hormone and $T_{4}$ stimulate synthesis of body proteins to replace those proteins inactivated by dimethyl disulphide.

The authors thank Mrs R. W. Harrex, Mr A. W. Williams, Mr S. J. Duncan and Mrs J. Crosbie for technical assistance, and Dr C. G. Mackintosh for carrying out the adipose tissue biopsies. 


\section{REFERENCES}

Bailey, R. W. (1967). New Zealand Journal of Agricultural Research 10, 15-32.

Barry, T. N., Duncan, S. J., Sadler, W. A., Millar, K. R. \& Sheppard, A. D. (1983). British Journal of Nutrition 49, 241-253.

Barry, T. N., McDonald, R. C. \& Reid, T. C. (1981 a). Journal of Agricultural Science, Cambridge 96, $257-267$.

Barry, T. N., Manley, T. R. \& Duncan, S. J. (1984a). Journal of Agricultural Science, Cambridge 102, $479-486$.

Barry, T. N., Manley, T. R. \& Millar, K. R. (1982a). Journal of Agricultural Science, Cambridge 99, 1-12.

Barry, T. N., Manley, T. R., Millar, K. R. \& Smith, R. H. (1984b). Journal of Agricultural Science, Cambridge 102, 635-643.

Barry, T. N., Manley, T. R., Redekoop, C., Davis, S. R., Fairclough, R. J. \& Lapwood, K. R. (1982b). British Journal of Nutrition 47, 319-329.

Barry, T. N., Reid, T. C., Millar, K. R. \& Sadler, W. A. (1981 b). Journal of Agricultural Science, Cambridge 96, 269-282.

Bauman, D. E. \& Davis, C. L. (1975). In Digestion and Metabolism in the Ruminant, pp. 496-509 [I. W. McDonald and A. C. I. Warner, editors]. Armidale: University of New England Publishing Unit.

Chopra, I. J. \& Solomon, D. H. (1980). In Endocrinology 1980, p. 235 [I. A. Cumming, J. W. Funder and F. A. O. Mendelsohn, editors]. Canberra: Australian Academy of Science.

Gluckman, P. D. \& Butler, J. H. (1983). Journal of Endocrinology 99, 223-232.

Gosden, A. F. (1979). Journal of the Science of Food and Agriculture 30, 892-898.

Larsson, L., Golterman, N., Magistris, L. D., Rehfeld, J. E. \& Schwartz, T. W. (1979). Science 205, $1393-1395$.

McDowell, G. H., Hart, I. C., Bines, J. A. \& Lindsay, D. B. (1983). Proceedings of the Nutrition Society of Australia 8,165 .

Morley, J. E., Garvin, T. J., Pekary, E. A. \& Hersham, J. M. (1977). Biochemical and Biophysical Research Communications 79, 314-318.

Pike, B. V. \& Roberts, C. J. (1980). Research in Veterinary Science 29, 108-110.

Pike, B. V. \& Roberts, C. J. (1981). Research in Veterinary Science 30, 390-391.

Rivier, J., Spiess, J., Thorner, M. \& Vale, W. (1982). Nature 300, 276-278.

Schmidt, S. P., Smith, J. A. \& Young, J. W. (1975). Journal of Dairy Science 58, 952-956.

Smith, R. H. (1974). Report of the Rowett Research Institute 30, 112-131.

Trenkle, A. (1980). In Digestive Physiology and Metabolism in Ruminants, pp. 505-522 [Y. Ruckebusch and P. Thivend, editors]. Lancaster: MTP Press.

Trenkle, A. (1981). Federation Proceedings 40, 2536-2541.

Trinder, P. (1969). Annals of Clinical Biochemistry 6, 24-27.

Ulyatt, M. J. (1973). In Chemistry and Biochemistry of Herbage, pp. 131-178 [G. W. Butler and R. W. Bailey, editors]. London: Academic Press.

Wallace, A. L. C. (1979). In Physiological and Environmental Limitations to Wool Growth, pp. $257-268$ [J. L. Black and P. J. Reis, editors]. Armidale, Australia: University of New England Press.

Wheatley, I. S., Wallace, A. L. C. \& Bassett, J. M. (1966). Journal of Endocrinology 35, 341-353.

Wieland, O. (1974). In Methods of Enzymatic Analysis, vol 3. pp. 1404-1409. [H. U. Bergmeyer, editor]. Berlin: Verlag Chemical. 